\title{
気体軸受圧カによる磁気ディスク媒体及びスライダの表面変形
}

市原 順一 ${ }^{* 1}$

\section{Surface deformation of magnetic disk and slider caused by air bearing pressure}

\author{
Jun-ichi ICHIHARA*1 \\ ${ }^{* 1} 1157$ Ichigaocho, Aobaku, Yokohama 225-0024, Japan
}

Received: 29 August 2017; Revised: 9 November 2017; Accepted: 13 December 2017

\begin{abstract}
The slider/disk spacing of magnetic disk drives has been reduced in order to increase the recording density. Especially, the thermal flying-height control technology, where the electromagnetic transducer is protruded into the slider/disk spacing by heating the slider partially, contributes to make the flying height less than $2 \mathrm{~nm}$. Because of the narrower gas bearing clearance, the bearing pressure rises up to several tens times of atmospheric pressure. This pressure rise causes the deformation of slider and disk surface. The slider and disk surface deformation causes the change of gas bearing clearance and consequently the change of air bearing pressure. The pressure change causes the flying attitude. The flying characteristics also may be different from that of expected at the design, where the effect of deformation is not included. It is important to estimate correct flying characteristics affected by the deformation to realize stable flying and accurate recording. We introduced iterative method for searching the flying attitude affected by the slider/disk deformation. We obtained the air bearing pressure by solving the molecular gas lubrication equation numerically. And the simple numerical method, which utilizes the elastic half-space assumption, was employed for calculating the deformation of pressurized disk surface. The finite element method was applied to analyze the slider deformation. And the effect of deformation on the slider attitude is evaluated.
\end{abstract}

Keywords : Hard disk drive, Head slider, Flying height, Surface deformation, Finite element method

\section{1. 緒言}

磁気ディスク装置（HDD）は低コストの大容量記憶装置としてデータセンタ等で使用される他，近年は AV 家 電等にも使われるようになっている. 現在 1 テラビット／平方インチ以上の記録密度が達成されているが，ビッ グデータの活用等で年々保存データ量が増加しており, 磁気ディスク装置の高密度・大容量化の要求はますます 高まっている．高密度化の観点からは記録ビットセルのさらなる微小化が求められる.このためには磁気ディス ク媒体と，この表面上を浮上する気体軸受スライダに搭載されている磁気へッドとのすき間をより一層小さくす る必要がある．特に近年は熱突出し（Thermal Fly-height Control）という技術の採用により最小浮上すき間が $2 \mathrm{~nm}$ 以下にまで低下している，熱突出しは磁気ヘッド素子内部にヒータを配置し，記録再生時のみこれに通電するこ とによって磁気ヘッド近傍だけを熱膨張させ媒体側に突出し，磁気へッドを媒体に近接させる方法である．熱突 出し量が最大となる磁気へッド近傍ではスライダと媒体間の浮上すき間は例えば数ナノメートルと微小になる. このためこの上流域では動圧効果により非常に大きな圧力が発生する. この圧力は時として数十気圧に達するこ ともある. この局所的高圧によってスライダあるいは媒体表面が変形することが予想され，さらにこの変形によ りスライダの浮上量や浮上姿勢が変化する可能性がある。これまでのスライダ設計ではこのような変形の影響ま では考慮されていないので，変形による浮上状態の変化，特に磁気へッドと媒体間のすき間変化が予想しない記

No.17-00373 [DOI:10.1299/transjsme.17-00373], J-STAGE Advance Publication date : 21 December, 2017

${ }^{* 1}$ 正員（干225-0024 神奈川県横浜市青葉区市ヶ尾町 1157）

E-mail of corresponding author: ichijichij@gmail.com 


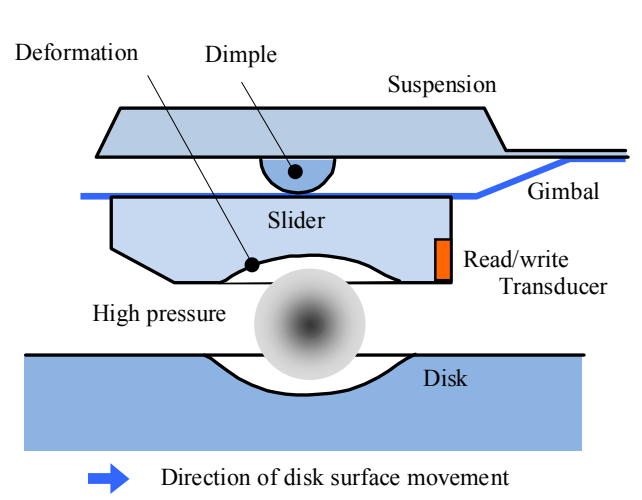

Fig.1 Slider/Disk deformation by bearing pressure

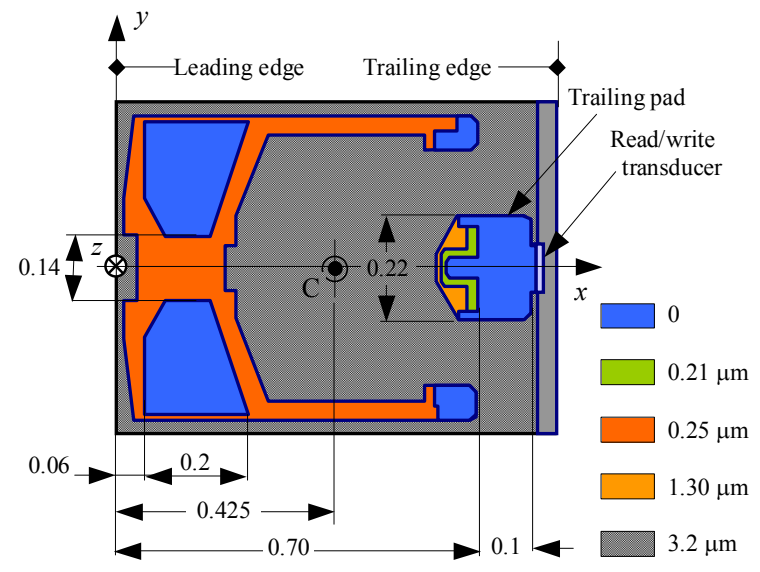

Fig.2 ABS of tested slider

録再生特性の劣化をもたらす可能性がある. 信頼度の高い記録特性を実現するうえで，変形の影響を含めたスラ イダ浮上特性の解析が設計上重要である.

本報告では気体軸受発生圧力による媒体及びスライダの変形に関してより簡便な計算手法を導入し，この手法 を用いて媒体・スライダ変形の特徵を明らかにした．さらに媒体・スライダ変形がある場合のスライダの定常浮 上量・浮上姿勢の探査手法を提案し，この手法を用いて変形が浮上姿勢に与える影響についても調查した.

\section{2. スライダ及び媒体変形解析}

スライダ気体軸受の構造と発生圧力による変形の様子を模式的に図 1 に示す．このように変形はスライダ及び 媒体双方で発生する．両者の変形を計算するには例えば三次元有限要素解析が必要となる，媒体の場合ではスラ イダ気体軸受面（Air Bearing Surface：ABS）から十分遠方で，軸受圧力による媒体の歪が無視できる点での変形 をゼロとする境界条件を設定して計算することになる. 求めたいのは ABS に対応する領域での媒体の変形である のに，これよりはるかに広い解析領域が必要となり計算時間・記憶容量の点から負荷の高い計算となる. 本報告 では最終的に軸受圧力による変形が浮上姿勢に与える影響を評価したい. このためには, 諸条件と ABS 形状から 支持系とバランス寸る浮上姿勢と圧力分布を計算し，圧力分布から媒体・スライダの変形を求め，これを用いて ABS 形状を更新し再び浮上姿勢及び圧力分布を計算する, という処理を繰り返す. この処理は圧力分布／媒体・ スライダ変形が収斂するまで繰り返され，定常的な媒体・スライダ変形が求められることになる. このような過 程で大規模な三次元弾性解析が含まれることは計算上大きな負担となる. そこで本報告では, 気体軸受圧力によ る媒体変形に関してより簡単な計算手法を導入する (この手法の妥当性についても検証する).また潤滑膜, 保護 膜や磁性膜の影響は無視し，媒体・スライダとも一様な材料特性を持つものとしている．媒体・スライダの弾性 係数はそれぞれ $E_{d}=130 \mathrm{GPa}, E_{s}=390 \mathrm{GPa}$, Poisson 比は $v_{d}=0.30, v_{s}=0.21$ である. さらに軸受すき間内の気体の 粘性摩擦力，スライダと媒体間に作用する van der Walls 力は変形に寄与しないものとして無視している.

\section{$2 \cdot 1$ 供試スライダ及び圧力分布}

計算の対象とするのは Femto スライダ（長さ : $L=0.85 \mathrm{~mm}$ ，幅 : $B=0.70 \mathrm{~mm}$ ，厚さ : $t=0.23 \mathrm{mm）である.}$ 図 2 にこのスライダの ABS を示す. 青色で示寸最表面からエッチングにより 4 段階の段差が加工されている. こ こでスライダ長手方向を $x$, 幅方向を $y$ とする座標系を設定する. 図の左側 $(x=0)$ が流入端で媒体の回転に伴 って気体が流入する. 右側が流出端で磁気ヘッドが配置されている. $y$ の正の方向が媒体の外周側となる. $x=0.425$ $\mathrm{mm}, y=0.0$ がスライダ中心 : $\mathrm{C}$ となり $\mathrm{ABS}$ 背面でこの位置に対応寸る点がディンプルで支持され, サスペンシ ヨン負荷が加えられる．同時に，この点が圧力中心となるように ABS は設計される.

気体軸受で発生する圧力は数值的に求められる (Hu and Bogy, 1998). ABS を構造格子で分割し, 各格子点周り のコントロール・ヴォリュームにおいて質量保存則を定式化する.この際の質量流量の算出においては分子気体 潤滑理論（Fukui and Kaneko, 1988）に Patanker 近似（Patanker, 1980）を適用している。この結果得られた連立方 
Table 1 Flying condition and static characteristics

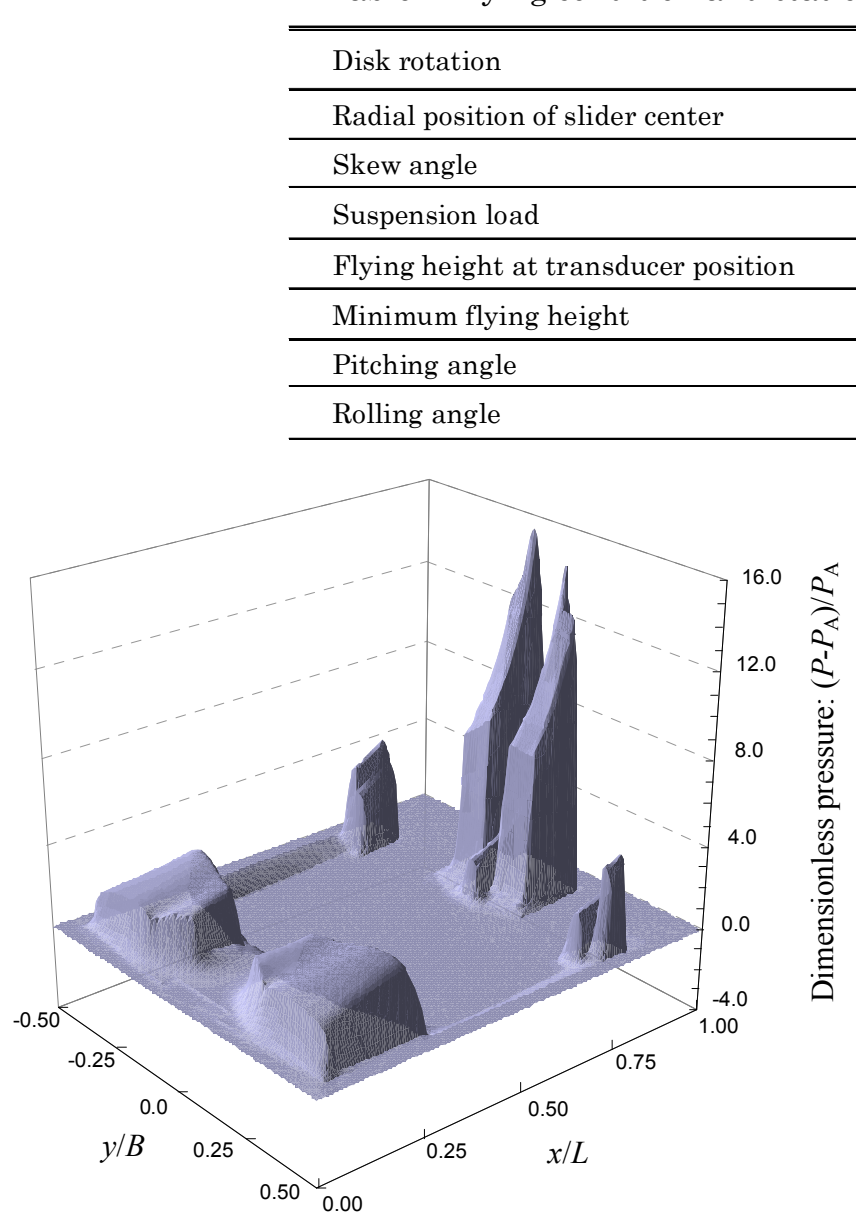

Fig.3 Bird's-eye view of pressure distribution

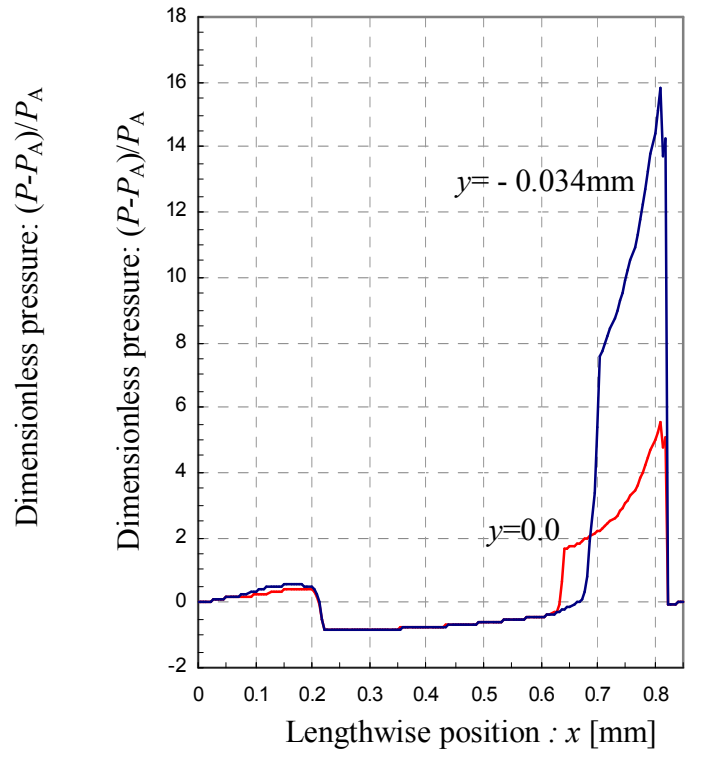

Fig.4 Pressure distribution along the $x$ axis.

程式をマルチグリッド法（Shyy and Sun, 1993）と ADI 法（Peaceman, 1955）を用いて解くことにより圧力を求め る. 圧力分布を積分して軸受発生力，圧力中心位置を求め，これらがそれぞれサスペンション負荷及びスライダ 中心位置（ディンプル支持点）と一致するよう繰り返し計算を行い，スライダ浮上姿勢及びすき間を求める。こ の姿勢探査過程では準ニュートン法（Dennis and Schnabel, 1996）を用いた. スライダの浮上条件と最終的に得ら れた静浮上特性を表 1 に示す. 図 3 は定常浮上時の軸受圧力分布 : $P(x, y)$ の計算結果を鳥瞰図で示す. 圧力はスラ イダ周囲圧力: $P_{A}$ を用いて無次元化している. 図 4 は $x$ 軸方向に沿った圧力分布で $y$ 軸方向の位置を変えて示す. $y=-0.034 \mathrm{~mm}$ を通る直線上で圧力は最大值をとる. 流出端近傍では大きな圧力が発生し, 流入端のパッド部でも 比較的大きな圧力が発生する. 一方，スライダ中央部では負圧が発生している. このような圧力分布を実現する ことにより，スライダの各変位モードでの剛性を高め，媒体表面追従特性の高い磁気ヘッド支持系を構成してい る. なお，数值計算に当たって $x$ 軸方向 : 576 分割， $y$ 軸方向 : 480 分割の等分割構造格子を用いている. 通常の Femto スライダでは $200 \times 200$ 程度の分割で十分な計算精度が得られることが多い (Hu and Bogy, 1998).しかし， 後にその圧力分布を示す熱突出しを適用した場合, 熱膨張に伴う急峻な変形が ABS に重畳され, これに対応する ため $576 \times 480$ というより精細な分割を採用した. これ以上細分化しても熱突出し時のスライダ特性（軸受発生 力, 圧力中心, 等) が殆ど変化しないことを確認し, 精度的に十分精細な分割であると判断した. また後述する 変形計算でこの圧力分布を使用する際は，変形解析時の分割に従って圧力を内挿補間して用いている.

\section{$2 \cdot 2$ 媒体変形解析}

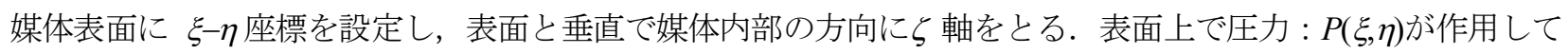
いるとき媒体が半無限弾性体であると仮定すれば（磁気ディスク媒体が半無限弾性体として扱えるかどうかとい 




Fig.5 Mesh arrangement for calculation of surface deformation



Fig.6 Disk surface deformation calculated by using the elastic half-space assumption. The deformation distribution is similar to the pressure distribution.

う点に関しては付録にて論ずる), 表面上の点 : $(\xi, \eta)$ における $\zeta$ 軸方向の変位 $: w(\xi, \eta)$ は次のように与えられ る (Popov, 2010).

$$
w(\xi, \eta)=\frac{1-v_{d}^{2}}{\pi E_{D}} \iint_{\infty} \frac{P\left(\xi^{\prime}, \eta^{\prime}\right)}{\sqrt{\left(\xi-\xi^{\prime}\right)^{2}+\left(\eta-\eta^{\prime}\right)^{2}}} d \xi^{\prime} d \eta^{\prime}
$$

$\xi-\eta$ 平面上で図 5 に示すような構造格子を考え, 式(1)の積分を離散的に行う. 格子点 $(i, j)$ 及びこの周囲（網 掛け部） で圧力が一定： $P_{i, j}$ であると仮定すると，この圧力による格子点 $(m, n)(m \neq i, n \neq j)$ における $z$ 軸方向 表面変位 : $\Delta w_{m, n, i, j}$ は式(1)に従って次のように近似できる.

$$
\begin{aligned}
\Delta w_{m, n, i, j} & =\frac{1-v_{d}^{2}}{\pi E_{D}} \frac{P_{i, j}}{\sqrt{\left(\xi_{m}-\xi_{i}\right)^{2}+\left(\eta_{n}-\eta_{j}\right)^{2}}} \Delta \xi_{i} \Delta \eta_{j} \\
\Delta \xi_{i} & =\frac{\xi_{i+1}-\xi_{i-1}}{2} \\
\Delta \eta_{j} & =\frac{\eta_{j+1}-\eta_{j-1}}{2}
\end{aligned}
$$

また，格子点 $(m, n)$ の周囲 : $\Delta \xi_{m} \times \Delta \eta_{n}$ に一定圧力 $: P_{m, n}$ が作用しているとき，この圧力による点 $(m, n)$ での変位： $\Delta w_{m, n, m, n}$ は次のように与えられる (Johnson, 1985).

$$
\begin{aligned}
\Delta w_{m, n, m, n} & =\frac{\left(1-v_{d}^{2}\right) P_{m, n}}{\pi E_{D}}\left[\Delta \xi_{m} \ln \left\{\frac{1+\sin (\phi)}{1-\sin (\phi)}\right\}+\Delta \eta_{n} \ln \left\{\frac{1+\cos (\phi)}{1-\cos (\phi)}\right\}\right] \\
\phi & =\tan ^{-1}\left(\frac{\Delta \eta_{n}}{\Delta \xi_{m}}\right)
\end{aligned}
$$

結局, 格子点 $(m, n)$ での変位: $w_{m, n}$ は圧力の作用するす心゙ての格子点に対する和をとって次のように与えられる.

$$
w_{m, n}=\sum_{i, j} \Delta w_{m, n, i, j}
$$

媒体が半無限弾性体であると仮定することにより表面変形を二次元解析で求めることができ，計算規模は三次元 有限要素法等と比較してはるかに小さくなる.

図 6 は図 3,4 に示寸圧力が作用した場合の媒体表面変位を式(4)に従って計算したもので，媒体が凹面となる 方向の変位が正であるとしている. ABS に対応寸る媒体表面の領域を $x$ 軸方向に $180, y$ 軸方向に 148 それぞれ 等分割している $(\Delta x=4.72 \mu \mathrm{m}, \Delta y=4.73 \mu \mathrm{m})$. 弾性変形は急峻な加圧力分布に対してもなだらかな変化をする傾向 があり，より精細な分割（例えばスライダ圧力分布計算時と同じ）を行っても計算結果は殆じ変化しない. 図に 


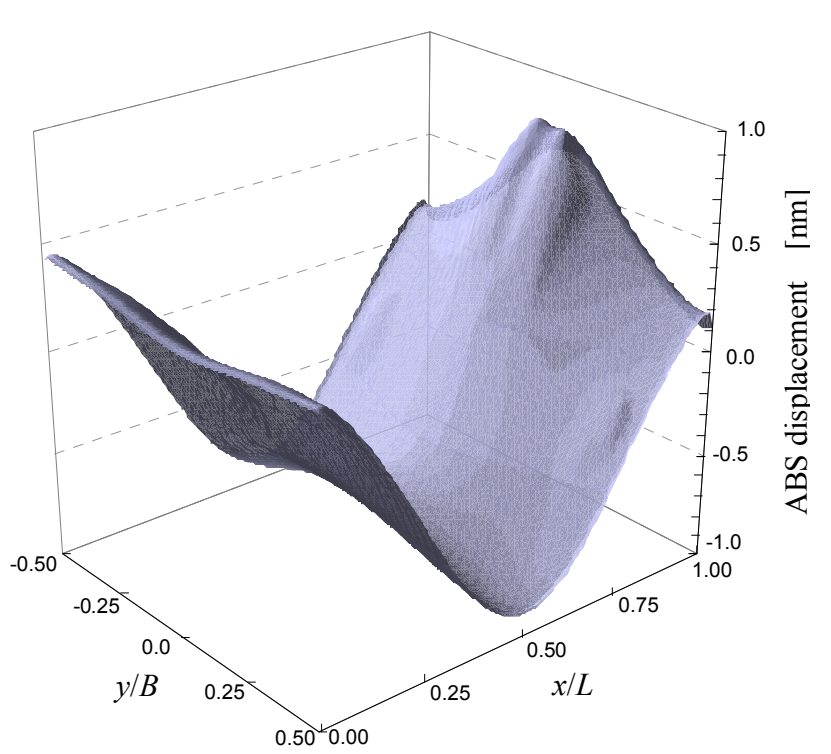

Fig.7 Slider surface deformation calculated by using the $3 \mathrm{D}$ finite element method. The bending dominates the slider deformation. High pressure at around the leading and trailing edge causes the bending.

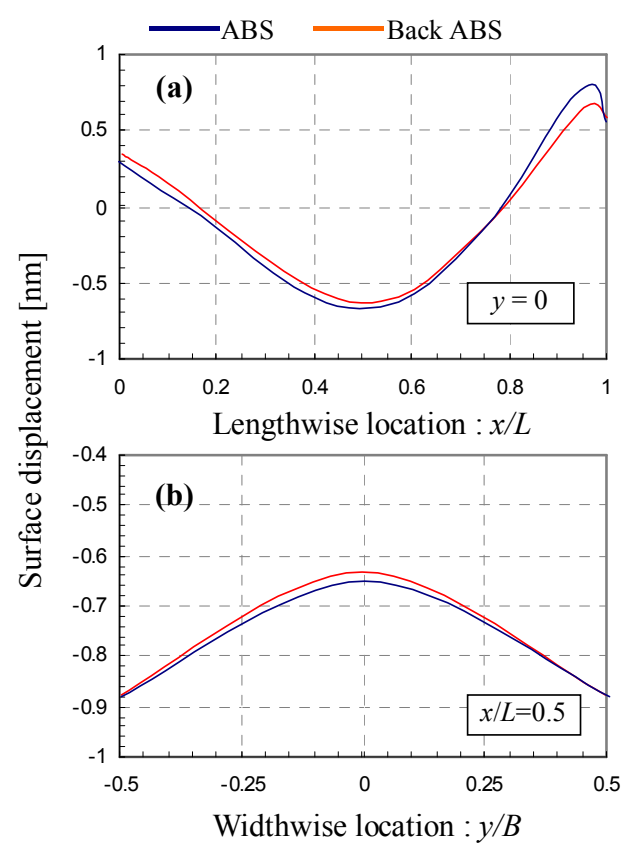

Fig.8 Slider deformation : (a) deformation along the $x$ axis and (b) deformation along the $y$ axis

示寸変形の分布は圧力分布と類似しているが空間周波数の高い成分が除去された滑らかな分布となっている．流 出端部で $1.03 \mathrm{~nm}$ の最大変位が生じている.

\section{$2 \cdot 3$ スライダ変形解析}

スライダの変形解析は三次元有限要素法を用いて行った． スライダを ABS 内で $x$ 軸方向に 180 分割, $y$ 軸方 向に 148 分割，厚さ方向に 48 分割して 8 節点直方体要素を用いた. スライダは図 1 に示すように ABS 背面でジ ンバルを介してディンプルと接触している．ここではジンバルを無視してディンプルとスライダ背面が直接接触 し，これが Hertz 接触（Johnson, 1985）であると仮定する. 気体軸受圧力によって ABS に作用する力とディンプ ル接触力がバランス寸るよう Hertz 圧力を設定する. スライダ表面では気体軸受圧力に応じた節点力を, 背面で は Hertz圧力に応じた節点力を与えている.ちなみにディンプル半径は $0.2 \mathrm{~mm}$, ディンプルの弾性係数は $190 \mathrm{GPa}$, Poisson 比は 0.31 としている（Li et al.,2009）。

図 7 は図 3，4 に示寸軸受圧力が ABS に作用した場合のスライダ変形を計算した結果を鳥瞰図で示す．図 8 は同じくスライダ変形で図 8(a)は $x$ 軸方向, (b)は $y$ 軸方向に沿った ABS と ABS 背面の変形を同時に示寸. 変形 は媒体から離れる方向（すき間が大きくなる方向）を正としている. ABS 及びその背面が同様な形で変形してい るので，スライダ中心周りの大きな撓みが発生していることが明らかである．流入・流出端部ですき間が大きく なる方向に変形し ABS 流出端部で最大 $0.889 \mathrm{~nm}$ 変位する.一方, 中央部ではすき間が小さくなる方向に最大 0.893 $\mathrm{nm}$ 変位する. スライダ中央部で負圧 (全負圧力 : $17.1 \mathrm{mN}$ ) が発生し, 流入・流出端部で正圧 (全正圧力 : $41.6 \mathrm{mN}$ ) が発生することにより大きな曲げモーメントが作用することが撓みの原因である．両端に正の力，中央部に負の 力が作用するような単純な梁でスライダをモデル化して撓みを計算すると, 例えば撓みの最大值では上の結果と 同じような值が得られる.

媒体では圧力分布の細かな変化が表面変形に反映されていたが, スライダの弾性係数が媒体のそれより 3 倍ほ ど大きいことも影響して，細かな圧力変化の影響は大きくない.

\section{3. 浮上姿勢への影響}

前章で気体軸受圧力による媒体表面及びスライダの変形の様子を明らかにした. 両者の変形の和に相当する分, 媒体・スライダ間の寸き間が変化しこれに伴ってスライダの浮上姿勢, 軸受圧力も変化し, したがって変形の様 


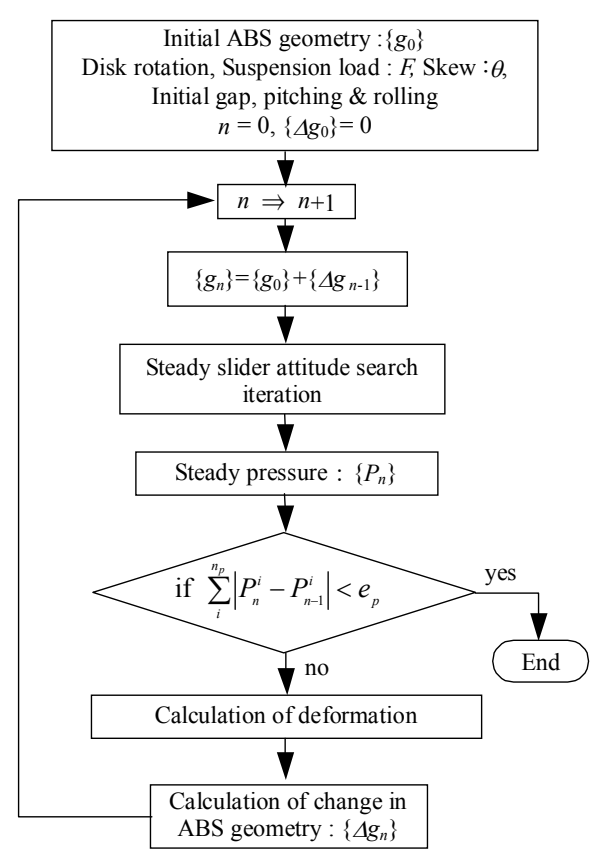

Fig.9 Procedure for searching the steady state slider/disk deformation and pressure. $\left(e_{p}=0.02 P_{A}\right)$

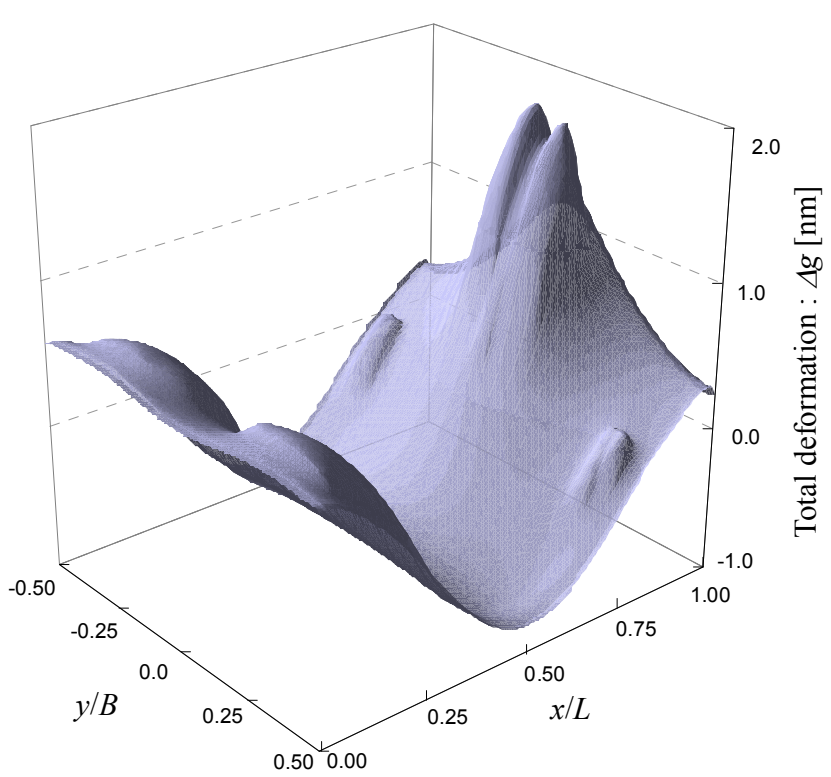

Fig.10 Final total deformation profile resulted from the procedure shown in figure 9.

(Total deformation $=$

Disk surface deformation + Slider ABS deformation)

Table 2 Steady flying attitude

(with effect of disk/slider deformation)

\begin{tabular}{c|ll}
\hline \hline Flying height at transducer & $12.54 \mathrm{~nm}$ & $(-0.13 \mathrm{~nm})$ \\
\hline Minimum flying height & $10.6 \mathrm{~nm}$ & $(-0.14 \mathrm{~nm})$ \\
\hline Pitching angle & $123.1 \mu$ radian & $(2.0 \mu$ radian $)$ \\
\hline Rolling angle & $-2.3 \mu$ radian & $(0.3 \mu$ radian $)$ \\
\hline
\end{tabular}

子も異なってくる，という再帰的な因果関係がある。ここでは圧力による変形が浮上姿勢に及ぼす影響を評価す る.

図 9 は圧力による変形がある場合の浮上姿勢の繰り返し探査手法を示寸. 圧力による両者の変形の和を ABS 形状の変化として扱う. $\left\{g_{0}\right\}$ は初期節点 $\mathrm{ABS}$ 形状, $\left\{g_{n}\right\}$ は繰り返し $: n$ における節点 ABS 形状で, 前の繰り返し で得られた節点 ABS 形状変化（媒体・スライダ変形和）: $\left\{\Delta g_{n-1}\right\}$ にって逐次更新される. ABS 形状に対して周 速, サスペンション負荷等の諸条件から, 2.1 節で述べた姿勢探査法を用いて力学的に平衡した定常浮上姿勢が求 められる.この結果として ABS 形状に適合した節点圧力: $\left\{P_{n}\right\}$ も得られる.この圧力による媒体・スライダ変形 を計算し ABS 形状変化：\{ $\left\{g_{n}\right\}$ を求める.この計算を繰り返し $\left\{P_{n}\right\}$ が一定值に収束した時点で変形の影響に対応 した圧力が求められたことになる. 繰り返し : $n$ での節点圧力 : $\left\{P_{n}\right\}$ と前回の節点圧力 : $\left\{P_{n-1}\right\}$ の差の全節点に対 する和が閾值 : $e_{p}$ 以下になったことで収束を判定している.

図 2 に示す ABS で表 1 の浮上姿勢を初期条件としてこの探查手法で求められた最終的な媒体・スライダ変形 和 : $\Delta g$ の分布を図 10 に, 浮上姿勢を表 2 に示す. 変形和は寸き間が大きくなる方向への変形を正としている. 表 2 には初期浮上姿勢（表 1）との差（括弧内）も示している. 当然のことながら変形和は媒体変形とスライダ 変形の特徵を併せ持ったものになっている．流出端部で浮上すき間が広くなる方向に最大 $1.80 \mathrm{~nm}$ ，スライダ中 央部で狭くなる方向に最大 $0.819 \mathrm{~nm}$ 変形している. 変形和はかなり大きいが，この影響を受けた浮上姿勢を初期 状態と比較するとその差は小さく, 例えば磁気ヘッド・トランスデューサ位置での浮上寸き間の差は $0.13 \mathrm{~nm}$ ある. 流出端部での浮上寸き間が拡大寸る方向への変形を補償するためピッチ角は増加している. 図 10 に示され る程度の変形では大きな浮上姿勢変化をもたらすことはないといえる. 初期状態からの差異が小さいということ 


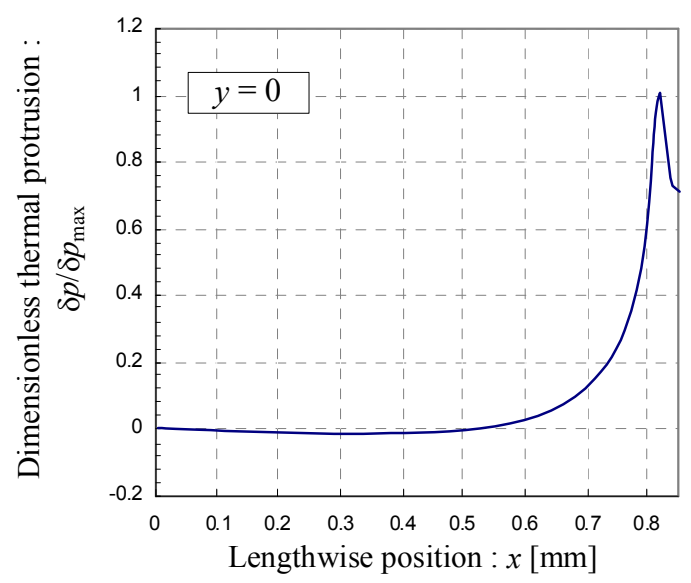

Fig.11 Distribution of thermal protrusion



Fig. 12 Pressure distribution with thermal protrusion



Fig.13 Total deformation profile with thermal protrusion

Table 3 Steady flying attitude $\quad($ thermal protrusion $=15.8 \mathrm{~nm})$

\begin{tabular}{c|c|c}
\hline \hline & Without effect of gap deformation & With effect of gap deformation \\
\hline Flying height at transducer & $5.56 \mathrm{~nm}$ & $5.82 \mathrm{~nm}$ \\
\hline Minimum flying height & $2.00 \mathrm{~nm}$ & $2.25 \mathrm{~nm}$ \\
\hline Pitch angle & $109.0 \mu$ radian & $112.3 \mu$ radian \\
\hline Roll angle & $-3.35 \mu$ radian & $-3.15 \mu$ radian \\
\hline
\end{tabular}

で，図 9 に示寸探査過程も，高々 4 回の繰り返しで収束する.

熱突出しを行った場合について同様な計算を行った. 図 11 は熱突出し量 : $\delta p$ の $x$ 軸に沿った分布を, その最大值： $\delta p_{\max }$ で無次元化して示寸. 加熱源が存在する流出端磁気ヘッド位置で突出し量が急激に大き くなる.この突き出しが ABS に重畳され, 熱突き出し時の ABS を形成する. 図 9 の探査過程を経て求めら れた熱突き出し時の無次元圧力分布を図 12 に示寸. 最大 $15.8 \mathrm{~nm}$ の熱突出しを行った場合で，圧力による 変形を考慮しない場合の最小浮上寸き間は $2 \mathrm{~nm}$ である.熱突出し先端部でスライダ周囲圧力の約 40 倍の急 峻な圧力上昇がみられる．図 13 は同じく媒体・スライダ変形和の計算結果である．流出端部で浮上すき間 が大きくなる方向に最大 $2.10 \mathrm{~nm}$, 中央部では狭くなる方向に最大 $0.839 \mathrm{~nm}$ 変形している. 熱突出しの無い 場合と比較すると最大発生圧力が増加したほどは変形和は大きくなっていない. これは熱突出しの場合, 大 
きな圧力の発生する範囲が非常に狭い領域に限られているため, 力としてはそれほど大きくないことによる. 熱突出しを行った場合について, 軸受圧力による媒体・スライダ変形の影響を考慮しない場合と考慮した場 合の浮上姿勢をまとめて表 3 に示寸.変形の影響を考慮した場合としない場合でトランスデューサ位置での 浮上寸き間には $0.26 \mathrm{~nm}$ の差があり, これは熱突出しの無い場合の差より大きいがそれでも十分小さいとい える.

本来スライダは, 媒体の振動や表面のうねりに対して磁気へッドと媒体間の間隔を一定值に保つような特性を 持っており, これは気体軸受の優れた特徴の一つである. 熱突出しの有無にかかわらず気体軸受圧力による媒体・ スライダの変形が，変形の大きさ程には浮上姿勢に影響しないという現象は，気体軸受という優れた間隔保持機 構が媒体・スライダの変形という現象に対しても機能している結果と考えられる.

\section{4. 結}

気体軸受圧力による媒体及びスライダの変形を解析し, 浮上姿勢への影響を調查した. 気体軸受圧力は分子気 体潤滑理論を適用したマルチグリッド法によって計算した。媒体表面変形については，気体軸受圧力に対して媒 体が半無限弾性体として扱えることを利用して，その表面変形を二次元解析で計算した．また，スライダ変形の 計算では，スライダ気体軸受面に作用寸る軸受力と軸受面背面でのディンプル接触力がバランス寸るという条件 を設定した三次元有限要素法を適用した。 この結果, 以下の結論を得た.

1 気体軸受圧力による媒体表面変形は圧力分布と略相似な分布となるが，圧力分布の空間高周波成分が除去さ れた滑らかな分布となる.

2 スライダ変形では気体軸受によって流入・流出両端で媒体から離れる方向の力が，中央部では媒体に近づく 方向の力が作用することによる全体の撓み変形が支配的であり, 細かな気体軸受圧力分布はスライダ変形に はあまり反映されない.

また, 圧力による媒体・スライダ変形を考慮した場合の定常浮上姿勢の探査手法を示し，この方法を用いて媒体・ スライダの変形が浮上姿勢にどのような影響を与えるか調查した．変形の影響を考慮した場合と考慮しない場合 とで浮上姿勢の差を比較した結果，両者の差はあまり大きくなかった．例えばトランシデューサ位置での浮上す き間に関しては，熱突出しの有無にかかわらず両者の差は $0.26 \mathrm{~nm}$ 以下であった。これは気体軸受支持スライダ が本来持っている間隔保持機能が，媒体振動やうねりの場合と同様，媒体・スライダ変形に対しても機能した結 果と考えられる. 結局, 気体軸受圧力による媒体及びスライダの変形は定常浮上姿勢にあまり大きな影響を与え ないものと判断される.

\section{References}

Dennis, Jr. J. E. and Schnabel, R. B., Numerical methods for unconstrained optimization and nonlinear equations (1996), pp.112-147, Society for Industrial and Applied Mathematics.

Fukui, S. and Kaneko, R., Analysis of ultra-thin gas film lubrication based on linearized Boltzmann equation, Transaction of ASME, Journal of Tribology, Vol.110, April (1988), pp.253-261.

Hu, Y. and Bogy, D. B., Solution of the rarefied lubrication equation using an additive correction based multigrid control volume method, Transaction of ASME, Journal of Tribology, Vol.120, April (1998), pp.280-288.

Johnson, K. L., Contact mechanics (1985), pp.53-62, Cambridge University Press.

Li, L., Etsion, I., Fanslau, E. B. and Talke, F., An analysis of the dimple/gimbal contact in a hard disk drive suspension, Proceedings of 2009 JSME-ISPS Joint Conference on Micromechatronics for Information and Precision Equipment (2009), HDI-03.

Patanker, S. V., Numerical heat transfer and fluid flow (1980), pp.90-91, CRC press.

Peaceman, D. W. and Rachford H. H., Jr., The numerical solution of parabolic elliptic differential equations, Journal of Society of Industrial and Applied Mathematics, Vol.3, No.1 (1955), pp.28-41.

Popov, V., Contact mechanics and friction (2010), pp.56-57, Springler.

Shyy, W. and Sun, C., Development of a pressure-correction/staggered-grid based multigrid solver for incompressible recirculating flows, Computers Fluids, Vol.22, No.1 (1993), pp.51-76. 


\section{付 録}

ここでは 2 章で示した媒体変形計算における,媒体が半無限弾性体であるという仮定の妥当性について検証す る. 磁気ディスク媒体の厚さ $t_{D}$ は媒体の直径に応じて異なり, メーカによっても若干の差異がある. 外形 3.5 inch 媒体では $t_{D}=1.27 \mathrm{~mm}$ が代表的であるが， $t_{D}=0.63 \mathrm{~mm}$ 程度が市場にある装置での最小值である. スライダで発生 する圧力に対してこのような厚さの媒体が半無限領域とみなせるから゙うかは疑問の余地があり検証の必要がある. 有限の厚さ $: t_{D}$ を持った平板部材に Hertz 圧力が作用する単純なモデルに関して軸対称有限要素解析を行い，こ れを半無限弾性体に対する解析解と比較して媒体厚さの影響を評価した.

平板部材表面の Hertz 圧加圧中心に対応する位置を原点とする座標系： $r-z$ を設定する. $r$ は加圧中心から測 った半径方向位置， $z$ 軸は加圧中心を通り部材表面と垂直で部材厚さ方向を正とする. 最大圧力を $P_{\max }$, 圧力の 作用する円の半径を $r_{p}$ とすると Hertz 圧力 : $P_{H}$ は次のように与えられる.

$$
P_{H}=\left\{\begin{array}{cc}
P_{\max } \sqrt{1-\left(r / r_{p}\right)^{2}} & r \leq r_{p} \\
0 & r>r_{p}
\end{array}\right.
$$

このとき半無限弾性体における $z$ 軸方向の表面変形 : $w_{H}$ は次のように与えられる (Johnson, 1985).

$$
\begin{aligned}
& w_{H}=\frac{1-v_{d}^{2}}{E_{d}} \frac{\pi P_{\max }}{4 r_{p}}\left(2 r_{p}{ }^{2}-r^{2}\right), r \leq r_{p} \\
& w_{H}=\frac{1-v_{d}^{2}}{E_{d}} \frac{P_{\max }}{2 r_{p}}\left\{\left(2 r_{p}{ }^{2}-r^{2}\right) \sin ^{-1}\left(r_{p} / r\right)+r^{2}\left(r_{p} / r\right) \sqrt{1-r_{p}^{2} / r^{2}}\right\}, r>r_{p}
\end{aligned}
$$

軸対称有限要素解析のモデルでは，加圧域半径 : $r_{p}$ に対して十分大きな半径 $; r_{b}$ を設定し，この半径位置が略 無限遠として境界条件を定める. $r$ 軸, $z$ 軸方向の変位をそれぞれ $u(r, z), w(r, z)$ とすると, 境界条件は以下のように なる.

$$
u(0, z)=0,\left.\frac{\partial w(r, z)}{\partial r}\right|_{r=0}=0, u\left(r_{b}, z\right)=0, w\left(r_{b}, z\right)=0
$$

解析領域 $\left(0 \leqq r \leqq r_{b}, 0 \leqq z \leqq t_{D}\right)$ を三角形要素に分割して変位 $: u, w$ を計算した。困 $\mathrm{A} 1$ は媒体表面 $(z=0)$ で の半径位置 : $r$ に対する $z$ 軸方向変位の計算結果である. 加圧域半径 : $r_{p}$ は $0.1 \mathrm{~mm}$ で, これは 2 章 1 節図 3 に示 した圧力分布で，高い圧力が大きくても半径 $0.1 \mathrm{~mm}$ の円内に収まる領域で発生していることを考慮して設定し ている. 最大圧力 : $P_{\max }=1 \mathrm{MPa}$, 媒体厚さ : $t_{D}=10 \mathrm{~mm}, r_{b}=5 \mathrm{~mm}\left(r_{b}=50 r_{p}\right)$ で, 媒体の弾性係数 : $E_{d}$, Poisson 比 : $v_{d}$ は第 2 章に示した. 有限要素法による数值解 : $w(r, 0)$ と半無限弾性体を仮定した場合の解析解 : $w_{H}$ を加圧域近

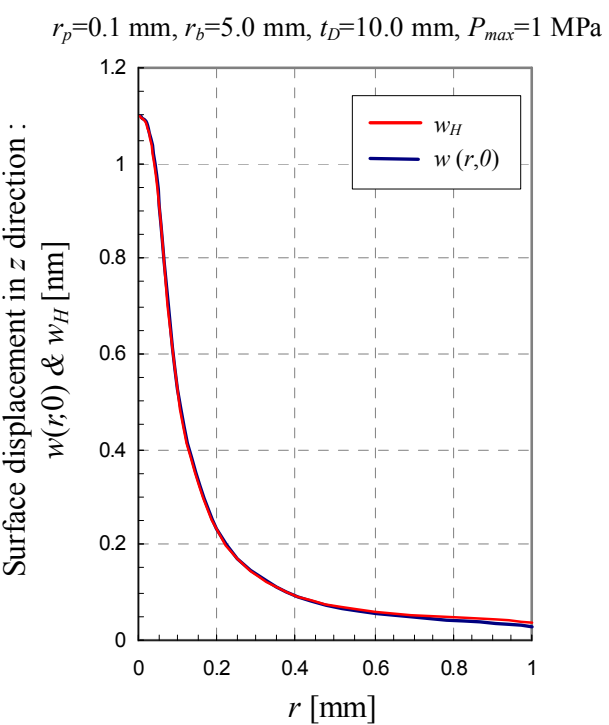

Fig.A1 Surface displacement for Hertz pressure. Comparison of results between the finite element method and the analysis using assumption of infinite half-space.



Fig.A2 Surface displacement for Hertz pressure. (a) Displacement in the radial area of $\left[0, r_{b}\right]$, and (b) Displacement in expanded radial area of $[0,1]$. 

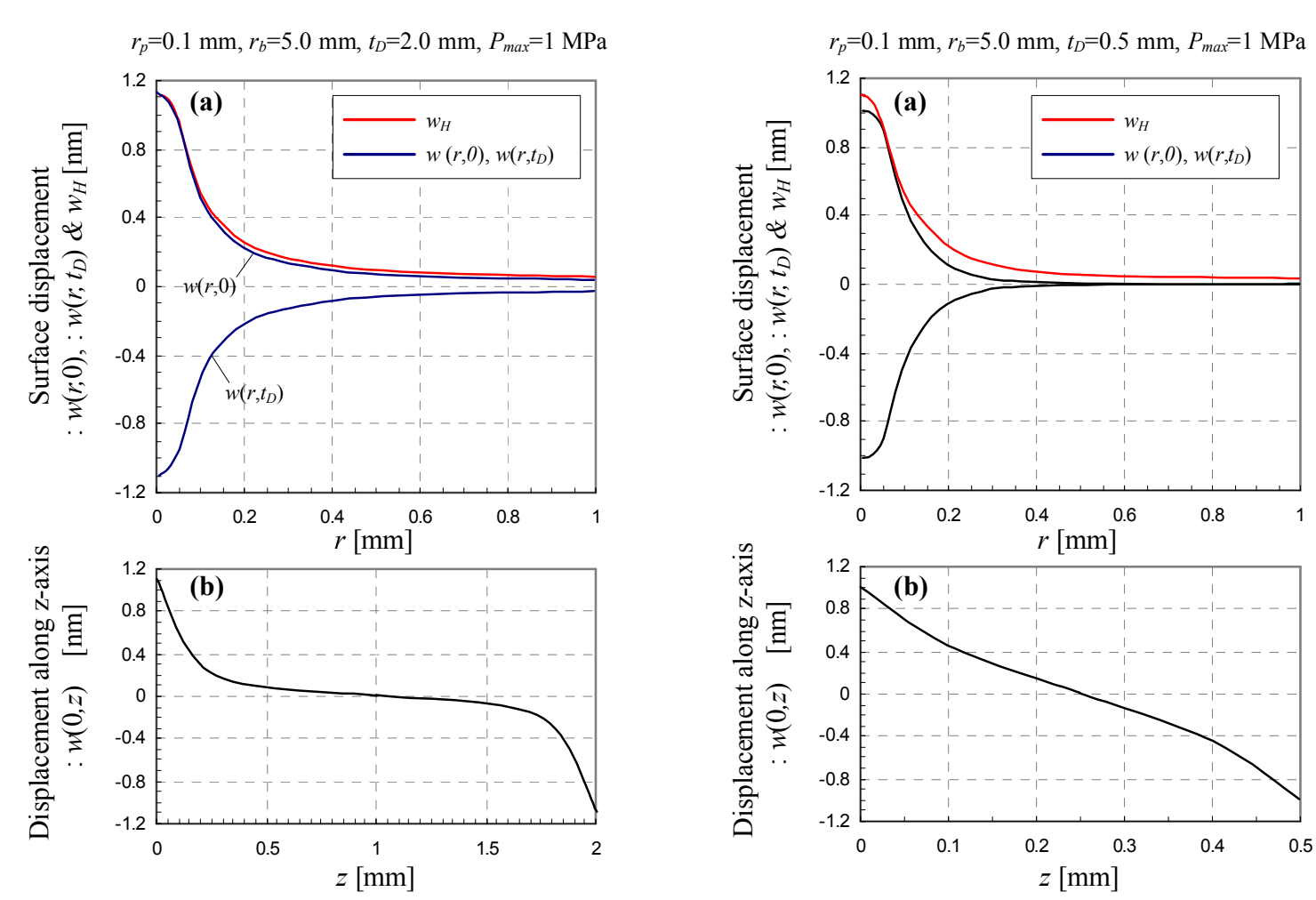

Fig.A3 Displacement for Hertz pressure. The pressure acts on either surfaces, though they scarcely affect each other.

Fig.A4 Surface displacement for Hertz pressure. The pressure affects on the displacement of both surfaces each other.

傍を拡大して示している．数值解は解析解と殆ど一致している．このことから，この媒体厚さに対しては半無限 弾性体という仮定が妥当であることがわかる. 図 A2 は図 A1 と同じ条件で媒体厚さ： $t_{D}$ だけを $1 \mathrm{~mm}$ にした場合 の計算結果である. 図 A2(a)は半径が 0 から $r_{b}$ の範囲を示し, 図 A2(b)は加圧域近傍 $(r=0 \sim 1 \mathrm{~mm})$ を示している. 媒体表裏での变位の数值解 : $w(r, 0), w\left(r, t_{D}\right)$, 解析解 : $w_{H}$ と共に, 表面変位から裏面変位を差し引いたもの $: \Delta w=$ $w(r, 0)$ - w $\left(r, t_{D}\right)$ を示している. この結果では媒体の撓みが大きいため数值解 : $w(r, 0)$ と半無限弾性体を仮定した解析 解 : $w_{H}$ (半無限弾性体では撓みは発生しない）の間には大きな差異がある. 一方, 表裏間の変位の差 : $\Delta w$ と解 析解： $w_{H}$ は殆ど一致している，媒体裏面の変位は媒体の大域的な撓みを反映しており，表裏の变位差は大域的な 媒体撓みの影響を除去した局所的変位を表している。したがって半無限弾性体を仮定した計算は，大域的な撓み の影響の無い場合の局所的変位をよく近似寸るといえる.

以上の結果から, 実際の磁気ディスク媒体では撓みの影響が大きくスライダ加圧に対して半無限弾性体として 扱うことができない. しかしながら磁気ディスク装置特有の使用条件についても考える必要がある. 磁気ディス ク装置では媒体の両面が記録面として使われ，2 個の磁気ヘッドスライダが媒体を介して対向するように配置さ れる. 両スライダでの圧力は媒体に対して面対称の関係となりその大きさ・分布も略等しい. したがって両面に 作用する力が平衡して媒体の撓みがなくなり, 図 A2 で示した $\Delta w$ のように変形は主に加圧中心近傍での局所的な ものとなる.このような変形に対しては半無限弾性体としての解析が高い精度の近似を与える可能性がある.

図 A3，図 A4 は媒体両面に同じ Hertz 圧力が作用している場合の $z$ 軸方向媒体変位を計算した結果で, 半径方 向に沿った表面及び裏面変位の数值解: $w(r, 0), w\left(r, t_{D}\right)$, 半無限弾性体と仮定した場合の表面変位の解析解: $w_{H}$ (各 図(a)), および加圧中心軸 $(r=0)$ に沿った $z$ 軸方向変位の数值解: $w(0, z)$ を示す (各図(b)). 加圧域半径は $0.1 \mathrm{~mm}$, 最大圧力は $1 \mathrm{MPa}$ ，媒体厚さは図 A3 が $2 \mathrm{~mm}$, 図 A4 が $0.5 \mathrm{~mm}$ である. 図 3(a)に示す，媒体厚さ $2 \mathrm{~mm}$ の場合の 表面変位の数值解: $w(r, 0)$ と, 半無限弾性体を仮定した解析解 : $w_{H}$ は $r$ の大きな範囲で若干の差異が見られるが よく一致する. また図 A3(b)に示す $z$ 軸に沿った変位を見ると, 変位は媒体表面から内部に向かうに従い速やか に減衰し, 厚さ方向の中点: $z=t_{D} / 2$ 付近でゼロに漸近寸る. 中点 $: z=t_{D} / 2$ では $z$ 軸方向歪 $: \varepsilon_{z}=\partial w / \partial z$ は殆ど ゼロである. 表裏両面の変位の影響が速やかに消滅し互いに影響しあわないという観点で媒体は十分厚く, 各面 での変位について半無限弾性体の仮定が適用できる. 図 A4 に示寸媒体厚さが $0.5 \mathrm{~mm}$ の場合では, 表面変位の数 




Fig.A5 Axial strain at the middle point of thickness versus substrate thickness.

值解：w(r,0)は半無限弾性体を仮定した解析解： $w_{H}$ より全般的に小さな值をとる. その差は最大 $0.1 \mathrm{~nm}$ 程度であ る. 図 A4(b) に示す $z$ 軸に沿った変位を見ると, 媒体内部での変位の減衰は緩慢で, 厚さ中点: $z=t_{D} / 2$ 付近でも $z$ 軸方向歪は大きな值を保っている. この場合は媒体が薄いことにより両面での加圧が互いに影響しあっている. 互いの面の圧力が変位を抑制しあうことにより，媒体厚さが薄くなるにつれて表面変位は減少する.

両面が加圧された媒体での半無限弾性体の仮定の適用可能性は, 両面が互いに影響しあうか否かによって判断 され, これは厚さ中点 : $z=t_{D} / 2$ での $z$ 軸方向歪 : $\varepsilon_{z}=\partial w /\left.\partial z\right|_{\mathrm{r}=0}$ を使って評価できる. 図 A5 は $\mathrm{z}$ 軸方向歪を媒体 厚さに対して数值計算した結果を示している.媒体厚さが $3 \mathrm{~mm}$ 以上では $z$ 軸方向歪は殆どゼロであり,概略 $2 \mathrm{~mm}$ 以上の媒体厚さに対して半無限弾性体の仮定が適用可能とするのが妥当と考えられる. しかしながら図 A4(a)の 結果から，媒体厚さ $0.5 \mathrm{~mm}$ の場合でも半無限弾性体の仮定によって得られた解は実際の場合の良い近似を与え ると考えてよいであろう。 